\title{
Article
}

\section{Pullout Behavior of Nail Reinforcement in Nailed Soil Slope}

\author{
Mahmoud H. Mohamed, Mohd Ahmed * and Javed Mallick if \\ Civil Engineering Department, College of Engineering, King Khalid University, Abha 61421, Saudi Arabia; \\ Mhosyan@kku.edu.sa (M.H.M.); jmallick@kku.edu.sa (J.M.) \\ * Correspondence: mall@kku.edu.sa; Tel.: +966-172-418-439
}

check for updates

Citation: Mohamed, M.H.; Ahmed, M.; Mallick, J. Pullout Behavior of Nail Reinforcement in Nailed Soil Slope. Appl. Sci. 2021, 11, 6419. https://doi.org/10.3390/app11146419

Academic Editor: Daniel Dias

Received: 23 June 2021

Accepted: 6 July 2021

Published: 12 July 2021

Publisher's Note: MDPI stays neutral with regard to jurisdictional claims in published maps and institutional affiliations.

Copyright: (c) 2021 by the authors. Licensee MDPI, Basel, Switzerland. This article is an open access article distributed under the terms and conditions of the Creative Commons Attribution (CC BY) license (https:/ / creativecommons.org/licenses/by/ $4.0 /)$.
Abstract: The pullout resistance and displacement performance of reinforcement have significant effects on the safe and economic design of a reinforced-soil system. In this study, the nail pullout tests are conducted to assess the pullout behavior of soil nail reinforcement at different levels in the soil slope of granular materials. The similitude laboratory models of a reinforced soil system with a scale of 1:10 are prepared. The construction sequence used in a full scale slope was precisely followed in the laboratory model. The models consist of a Perspex wall box filled with sand and steel bars as a reinforcement. The models of sand beds are formed using an automatic sand raining system. Devices and instruments are installed to record the nails pullout resistance and displacement. The tests are carried out at variable footing pressures to get the pullout force of the nails based on a strain control technique. The finite element models of nailed soil slope are also analyzed to validate the laboratory model results. It infers from the numerical model results that the laboratory models underestimate the pullout behavior of nail reinforcement in nailed soil slope. The pull-out force in nail reinforcement increases as the displacement increases and then decreases slightly and becomes constant with an increase in displacement in the case of deeper placed nails, but it becomes constant immediately for upper nails.

Keywords: soil nailing system; nails characteristics; soil slope; footing pressure; nails orientation; pullout force

\section{Introduction}

Soil nailing techniques are widely applied for the stabilization of slopes and excavations. The basic concept of reinforced-soil systems relies upon the transfer of resisting tensile force-generated nails into the soil through friction or adhesion mobilized at the inter-faces. The soil mass exerts the driving forces, i.e., lateral earth pressure on the weight of a potentially sliding soil mass while providing the nail bond resistance. The frictional interaction between the soil and nails restrains the soil movement during and after excavation. The pullout resistance and displacement performance of the reinforcement has significant effects on the safe and economic design of a reinforced-soil system [1]. The pullout resistance in a reinforced-soil system is influenced by many parameters, such as methods and construction processes, soil and nail properties, the interface roughness between soil and nails, and the geometry of the slope or excavation. Friction and adhesion at the interface between reinforcement and soil increases the stability by reducing the tensile strain in soil mass [2]. Panigrahi and Dhiman [3] have presented the design of the soil nailing system for landslide prevention and mitigation. They have also reviewed the various aspects and constraints related to soil nailing. The resistance factors for LRFD of soil nail pullout limits state under different design scenarios of nailed soil structures, that differ in wall face batter, soil friction angle, nail ultimate bond strength, and surcharge live load, are analyzed and calibrated by $\mathrm{Hu}$ and Lin [4] using artificial neural network (ANN) models. The progressive pullout response of a soil nail in reinforced soil systems is examined analytically by Hong et al. [5] They have considered the pullout process as three typical phase processes. The first is a pure elastic phase during which the nail-soil interface 
follows a linear elastic stress-displacement relationship, and then the elastic-plastic phase during which a transition point presents dividing the elastic and plastic zones and the final pure plastic phase. They have also performed a comprehensive parametric study to assess the effects of key factors, including length and diameter, length of plastic zone, and the elastic modulus of a soil nail, on the pullout resistance of a soil nail. The studies on the pullout behavior in soil nailing systems are due to Luo et al. [6], Su et al. [7] and Hong et al. [8] for various overburden pressure and conditions of soil dilation. The effect of rainfall infiltration on the behavior of soil nails in loose fill slopes is studied by Cheuk et al. [9] Pradhan et al. [10] have investigated through the experiments the soil-nail pullout interaction in loose fill materials. They have also simulated the pullout load-displacement relationship using a one-dimensional spring model. Chen et al. [11] have developed the novel nail pullout test to predict the soil-nail interface shearing mechanisms using short nails embedded in expansive cohesive soils under varying degrees of saturation. The effect of nails and soil parameters, namely size, length and angle of nails and friction coefficient at interface, on the pullout force for grouted soil nails in sandy soil are investigated experimentally and numerically by Ye et al. [12]. The accuracy of effective stress method (ESM) equations for the prediction of the ultimate bond strength of soil nails is assessed statistically by Lin and Liu [13] using the maximum likelihood method. Pullout behavior and the failure mechanisms of waste tire strip-reinforced sands are studied using the physical models by Li et al. [14] and they observed that the pullout resistance is initially provided by the front portion of the embedded tire strips and in the latter stages, more and more of the areas of the end portion of the tire strips are mobilized, giving a progressive failure mechanism. The pullout and bond resistance of soil nails of alluvium soil by considering the overburden pressure effect are evaluated by Moayed and Namae [15] using nail pullout physical models. The have observed that the bond resistance of soil nails increases as the overburden pressure increases in coarse grained soil, but the overburden pressure does not have a significant effect on the bond resistance in clay soil.

An analytical model was developed by Luo et al. [16] to predict the pullout resistance mechanism and they have shown that an apparent friction coefficient decreases with the increase of the applied normal confining pressure around the soil nail. Zhao et al. [17] have simulated the pullout behavior of a soil nails in a soil mass under different overburden pressures using the finite element technique. The constitutive relationship in soil is based on a modified Drucker-Prager/Cap model, while that of the soil-nail interface is described by a Coulomb friction model. The laboratory pullout tests are conducted by Tokhi et al. [18] on a new screw nail in sandy soil. The testing results indicate that the slip mechanism of screw soil nails is different, and that the resultant pullout capacity of screw soil nails is higher when compared with the conventional soil nails. The progressive shear strength mobilization along the embedment of the thread-bar grouted anchor is examined by Ruggeri et al. [19] using properly installed strain gauge monitoring. The grouted anchor is founded in the nonhomogeneous ground, a sand deposit followed by marly clay. They found from the results that a very low shear strength is offered by the sand and fast mobilization of the shear strength is in the marly clay at the deep end of the anchor. The behavior (pullout resistance) of a hollow and solid shaft helical soil nail installed in cohesionless soil were examined by Sharma et al. [20] under varying parameters such as helical soil nail properties, nail shaft types, installation torque, and overburden pressure. They have shown that additional helices will only contribute to pullout capacity if located outside the region of soil mobilized in the failure mechanism of a lower helix and solid shaft helical nails can be replaced by hollow nails without compromising on pullout capacity, adding to a reduction in construction cost. Ehrlich et al. [21] investigated the effect of excavation execution procedures on the behavior of nailed-soil structures using the finite element Code Plaxis 2D, 2015. The load transfer behavior of grouted anchors in laterite under long-term (creep) loads were investigated by Chen et al. [22] using laboratory and analytical models. The creep behavior on the grout-soil interface was represented using a Merchant rheological model. They observed that that the tensile force distribution in 
anchors tends to be linear, and that the shear stress distribution tends towards uniformity under long term conditions.

It is evident from the literature review that there is no simple way to accurately predict the pullout behavior for all types of nails in different soil types. There are numerous parameters affecting the pullout response of soil nails, including variation in soil conditions, variation in stress situation and variation in nail shape. Moreover, many parameters will change due to nail installation with time. Therefore, further studies are clearly needed to investigate the pullout behavior for soil nail reinforcement in nailed soil systems. In the present study, the nail pullout tests were conducted to assess the pullout behavior of soil nail reinforcement in granular materials. The development of soil shear resistance at the reinforcement-soil interface, i.e., soil-reinforcement interaction, is investigated in this study. Similar laboratory models of reinforced soil systems on a scale of 1:10 were prepared. The construction sequence used in a full scale slope was precisely followed in the laboratory model. The construction of a nailed soil slope system model, loading stages and pullout testing procedures were clearly defined. The models consisted of a Perspex wall box filled with sand and steel bars as a reinforcement. The models of sand beds were formed using automatic sand raining system. Devices and instruments were installed to record the nail pullout resistance and displacement. The tests were carried out at variable footing pressures to get the pullout force of the nails with a strain controller, taking a horizontal speed as $0.3 \mathrm{~mm} / \mathrm{min}$.

\section{Materials and Methods for Soil Nail Reinforcement Pullout Test}

The physical model of nail reinforced soil, including the materials used in the present study, is specially prepared to achieve a full similarity for the state of stresses and strains as the prototype and to avoid the effect of side friction in the model's walls. The dimensions of the model were selected with an appropriate scale factor (ratio between model and prototype) using the simulation and dimensional analysis to simulate the prototype as closely as possible and to make the material handling easy. The similitude, materials, experimental set-up, and construction procedure for the soil-nail reinforcement pullout test are described below.

\subsection{Simulation and Dimensional Analysis}

The stiffness parameters for the component of the soil nailing system are maintained for both model and prototype to achieve the correct similarity, i.e., flexibility number " $\rho$ " as per the following relationships:

$$
\begin{aligned}
\rho_{\text {model }} & =\rho_{\text {prototype }} \\
\left(\frac{H^{4}}{E I}\right)_{\text {model }} & =\left(\frac{H^{4}}{E I}\right)_{\text {prototype }}
\end{aligned}
$$

where $H=$ Excavation height (m); $E=$ Young's modulus of elasticity of components (kPa); $I=$ Moment of inertia per unit length of the components $\left(\mathrm{m}^{4} / \mathrm{m}\right)$.

If we consider a scale factor, $N$ equal to $\left(\mathrm{H}_{\text {prototype }} / \mathrm{H}_{\text {model }}\right)$ and the same material for the model and prototype, the moment of the inertia relationship between the model and the prototype becomes:

$$
I_{\text {model }}=I_{\text {prototype }}\left[\frac{E_{\text {prototype }}}{E_{\text {model }}}\right]\left[\frac{1}{N}\right]^{4}
$$

For the present study, the scale factor is taken as 10, so if the diameter of the model of the nail is $5 \mathrm{~mm}$, it simulates the actual nail of the diameter at $50 \mathrm{~mm}$. Considering the same density and shearing resistance of materials in the model and prototype soil, the length and spacing between the nails and applied footing pressure of the model are proportional to the prototype with the same ratio as the total excavation height ratio. 


\subsection{Soil Nailing System}

The soil nailing system consists mainly of backfill material, reinforcement, facing unit and strip footings. The air-dried clean siliceous yellow sand was used in the preparation of the models. The physical and mechanical properties of the tested sand were determined. The sand samples were tested for grain size distribution as per ASTM D421, specific gravity as per ASTM D854, minimum and maximum densities, moisture content and shear strength parameters as per ASTM D3080. Figure 1 shows the grain size distribution of several samples (two samples each for dry and wet sand) used. The physical properties of the soil materials are given in Table 1. Table 1 indicates that the tested sand was classified as poorly graded sand (SP) according to the unified soil classification system. It is known that the angle of internal friction $(\varphi)$ of sand depends on the relative density of the sample. Six samples were tested at different densities and varied from the relative density of $0.0 \%$ to the relative density of $100 \%$. Figure 2 shows the relationship between the angle of shearing resistance and the relative density. For pullout test, sand with a relative density of $48 \%$ and medium sand $\left(\gamma=16.41 \mathrm{kN} / \mathrm{m}^{3}\right)$, which has an angle internal friction $\varphi_{\text {medium }}$ as $34^{\circ}$.

Table 1. Physical and Mechanical Properties of Soil.

\begin{tabular}{cccc}
\hline Property & Value & Property & Value \\
\hline \% of Clay & 0.00 & Specific gravity $\left(\mathrm{G}_{\mathrm{s}}\right)$ & 2.62 \\
\% of Silt & 1.33 & Minimum density $\left(\gamma_{\min }\right)\left(\mathrm{kN} / \mathrm{m}^{3}\right)$ & 15.30 \\
\% of fine Sand & 39.17 & Maximum density $\left(\gamma_{\max }\right)\left(\mathrm{kN} / \mathrm{m}^{3}\right)$ & 17.80 \\
$\%$ of medium Sand & 58.63 & Minimum void ratio $\left(\mathrm{e}_{\min }\right)$ & 0.472 \\
$\%$ of coarse Sand & 0.87 & Maximum void ratio $\left(\mathrm{e}_{\max }\right)$ & 0.712 \\
$\%$ of fine Gravel & 0.00 & Angel of internal friction $\left(\phi^{\circ}\right)$ & 34 \\
Effective diameter $\left(\mathrm{D}_{10}\right) \mathrm{mm}$ & 0.126 & Bulk Density $\left(\gamma_{\mathrm{b}}\right)\left(\mathrm{kN} / \mathrm{m}^{3}\right)$ & 16.41 \\
Coefficient of uniformity $\left(\mathrm{C}_{\mathrm{u}}\right)$ & 1.99 & Void ratio $(\mathrm{e})$ & 0.597 \\
Coefficient of gradation $\left(\mathrm{C}_{\mathrm{u}}\right)$ & 1.00 & Relative density $(\%)$ & 48 \\
\hline
\end{tabular}

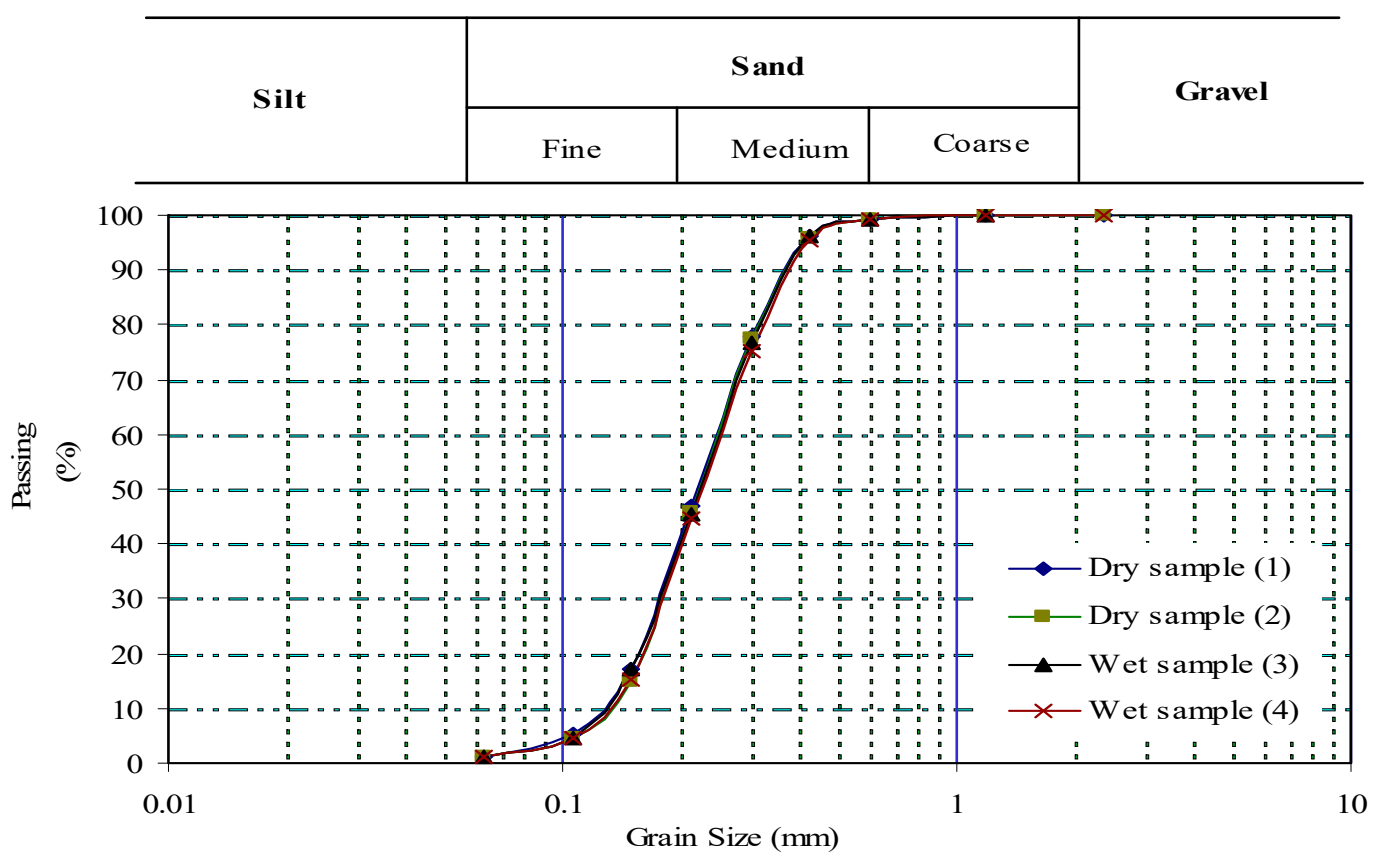

Figure 1. Grain size distribution of the tested sand. 


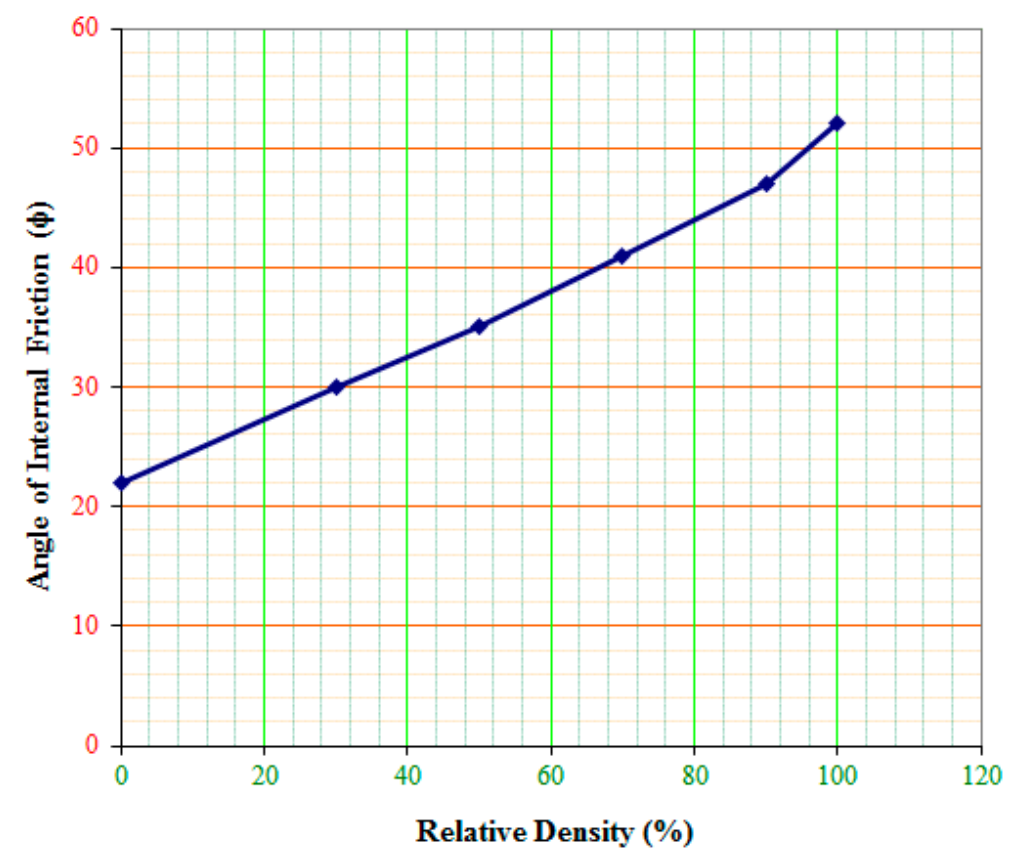

Figure 2. Relationship between relative density and angle of internal friction.

The nails used were steel bars of circular cross section with a constant diameter of $5 \mathrm{~mm}$ and lengths of $700 \mathrm{~mm}$. The nails were chosen to accommodate the electrical strain gauge. A direct tension test was performed to determine the strength characteristics of the nail. Figure 3 shows the stress-strain relationship for nail materials. The mechanical properties of nails are given in Table 2 .

Table 2. Properties of Reinforcement (Nails).

\begin{tabular}{|c|c|c|c|c|c|c|c|}
\hline Element & $\begin{array}{c}\text { Length } \\
(\mathrm{mm})\end{array}$ & $\begin{array}{c}\text { Maximum } \\
\text { Tensile Force } \\
(\mathbf{k N})\end{array}$ & $\begin{array}{l}\text { Strains at } \\
\text { Ultimate } \\
\text { Stress }(\mu \varepsilon)\end{array}$ & $\begin{array}{c}\text { Maximum } \\
\text { Tensile Strength } \\
(\mathbf{k P a})\end{array}$ & $\begin{array}{l}\text { Young's } \\
\text { Modulus } \\
(\mathrm{kPa})\end{array}$ & $\begin{array}{c}\text { Flexural } \\
\text { Rigidity, EI } \\
\left(\mathbf{k N} \cdot \mathbf{m m}^{2}\right)\end{array}$ & $\begin{array}{c}\text { Normal } \\
\text { Stiffness, EA } \\
(\mathrm{kN} / \mathrm{m})\end{array}$ \\
\hline $\begin{array}{c}5 \mathrm{~mm} \text { Steel } \\
\text { Nails }\end{array}$ & 700 & 17.4 & 7625 & $8.8 \times 10^{5}$ & $21.2 \times 10^{7}$ & $6.51 \times 10^{-3}$ & 4165.9 \\
\hline
\end{tabular}

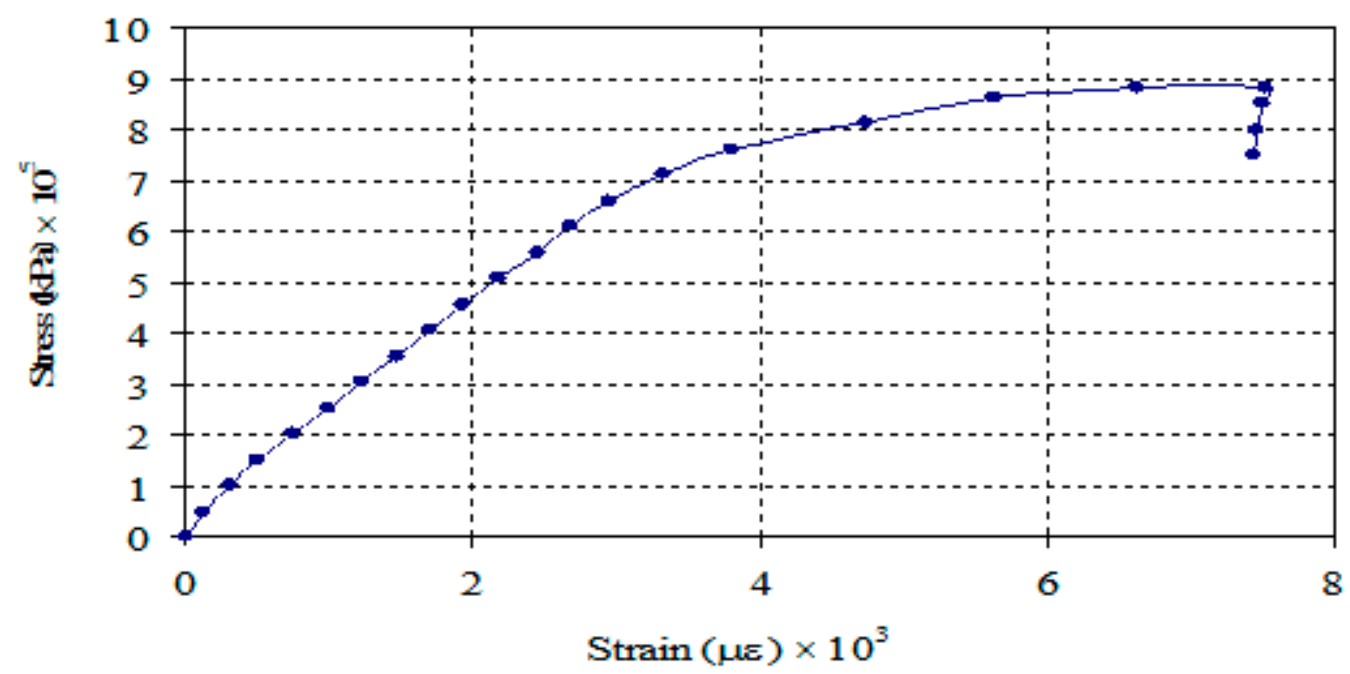

Figure 3. Stress-strain curve of the tested nail. 
The facing unit selected was a Perspex plate with a thickness of $5.0 \mathrm{~mm}$ to simulate the shotcrete in the prototype soil nailing system of a thickness of $140.0 \mathrm{~mm}$. The dimensions of the facing panel were $848.0 \mathrm{~mm}$ wide and $140.0 \mathrm{~mm}$ vertical (projected) in height. Holes of $8.0 \mathrm{~mm}$ in diameter were provided in panels to fix the nails' head. The size of footing has a direct influence on the size of the soil box. The size of footing is chosen as $185 \mathrm{~mm} \times 150 \mathrm{~mm} \times 22 \mathrm{~mm}$. The mechanical properties of facing and footing plate are given in Table 3. Figure 4 shows the slope facing and footing model used in the study.

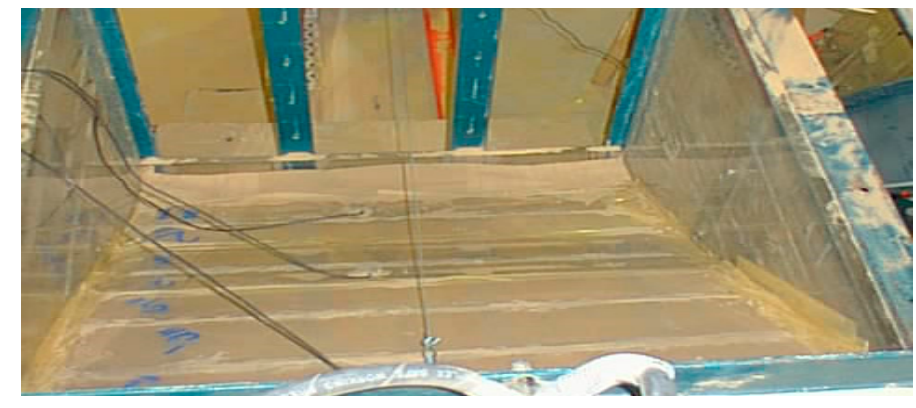

(a)

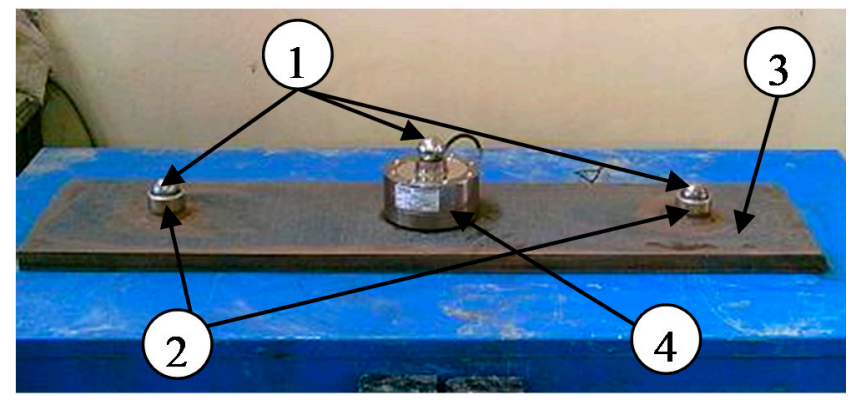

(b)

Figure 4. Slope facing details and footing model. (a) Slope facing; (b) footing model; 1: bearing ball; 2: welded stainless steel grooves; 3: steel plates; 4 : load cell.

Table 3. Properties of Facing and Footing Plate.

\begin{tabular}{|c|c|c|c|c|c|c|}
\hline Component & Material & $\begin{array}{c}\text { Width } \\
(\mathrm{mm})\end{array}$ & $\begin{array}{c}\text { Thickness } \\
\text { (mm) }\end{array}$ & $\begin{array}{l}\text { Young's } \\
\text { Modulus } \\
\text { (kPa) }\end{array}$ & $\begin{array}{c}\text { Bending } \\
\text { Stiffness } \\
\left(\mathrm{kN} \cdot \mathrm{mm}^{2}\right)\end{array}$ & $\begin{array}{c}\text { Axial } \\
\text { Stiffness } \\
(\mathbf{k N})\end{array}$ \\
\hline Facing & Perspex & 140 & 5.0 & 4200 & 0.04375 & 0.021 \\
\hline Footing & Steel & 150 & 22.0 & $21.2 \times 10^{7}$ & 188186.6 & 4665.78 \\
\hline
\end{tabular}

\subsection{Testing Box and Loading System}

The three dimensional model consisted of three main elements, namely, testing box, loading system and sand raining system. Following the similarity criteria described in previous section for the material and dimensions of the testing box, an open frontal Perspex box measuring $1760 \mathrm{~mm} \times 850 \mathrm{~mm} \times 1000 \mathrm{~mm}$ was used for the experimental work. The loading system was made of a loading frame, a loading frame base and a hydraulic loading system. The loading system was designed to prevent any disturbance to the nailed soil model. A density control apparatus was designed that employs sand raining techniques to get homogeneous sand beds in the testing box and to obtain the required relative densities. The sand placing device comprised three main units, namely, sand spreader, perforated plates, and a driven system. The sand spreader consisted mainly of a traveling hopper to discharge sand through a perforated plate fixed to the bottom of the hopper and a driven system to control the movement of the hopper backwards and forwards at certain speeds. In this study, the intensity of the fall of the sand was controlled by changing the size of the perforated base plate of the sand hopper and by changing the velocity of the hopper over the tank. After a series of preliminary tests, the size of perforations was chosen for each layer of $100 \mathrm{~mm}$ thick. Figure 5 shows the loading frame and sand raining system used in the study. The process of filling the testing box with sand is shown in Figure 6. The density of the sand bed was measured and controlled by placing temporary aluminum cylinders with no cover at locations (1-7) shown in Figure 5. The density of sand in the filled tank was measured using the eight permanent cylinders placed at different levels and the box was emptied very carefully until each cylinder was exposed. The final densities of sand measured at various levels in the box are presented in Figure 7. 


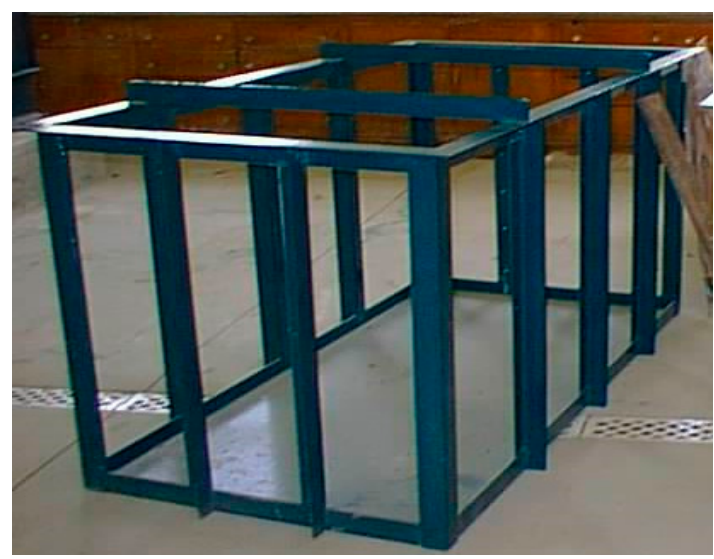

(a)

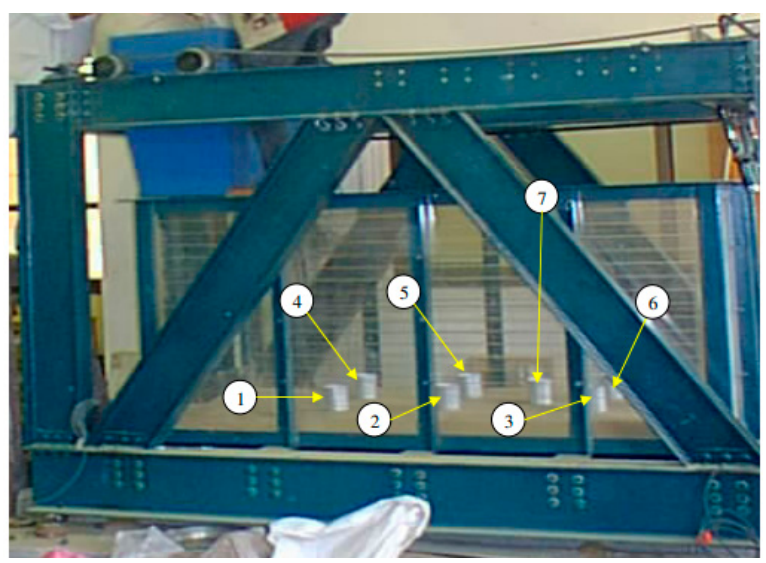

(b)

Figure 5. Testing box and loading frame including sand raining system; (a) Testing box; (b) Loading frame.

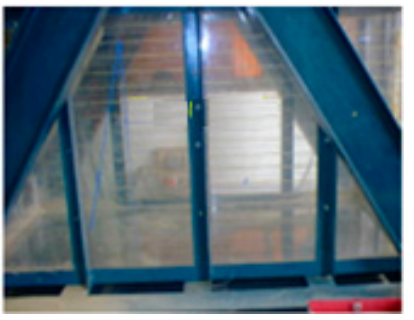

(a)

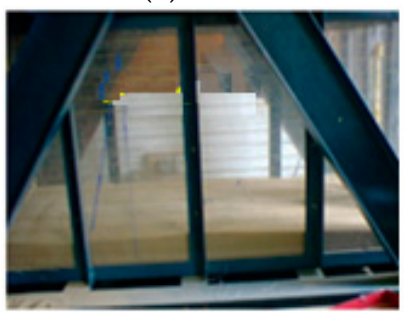

(e)

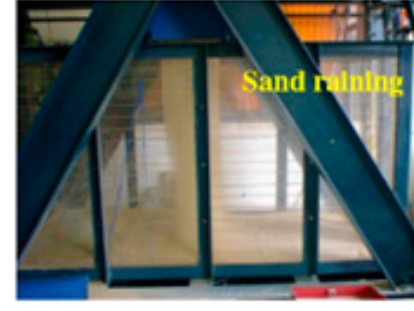

(b)

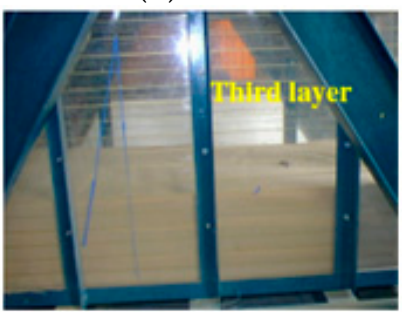

(f)

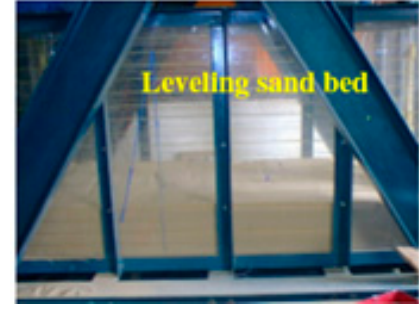

(c)

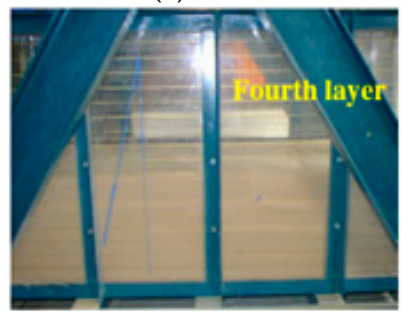

(g)

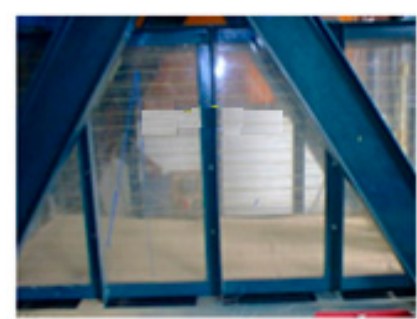

(d)

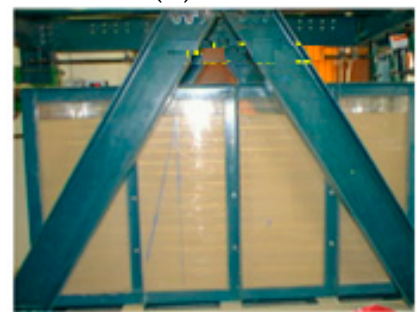

(h)

Figure 6. Process of placing the sand beds; (a) empty testing box; (b) sand raining; (c) levelling sand bed; (d) first layer; (e) second layer; (f) third layer; (g) fourth layer; (h) filled testing box.

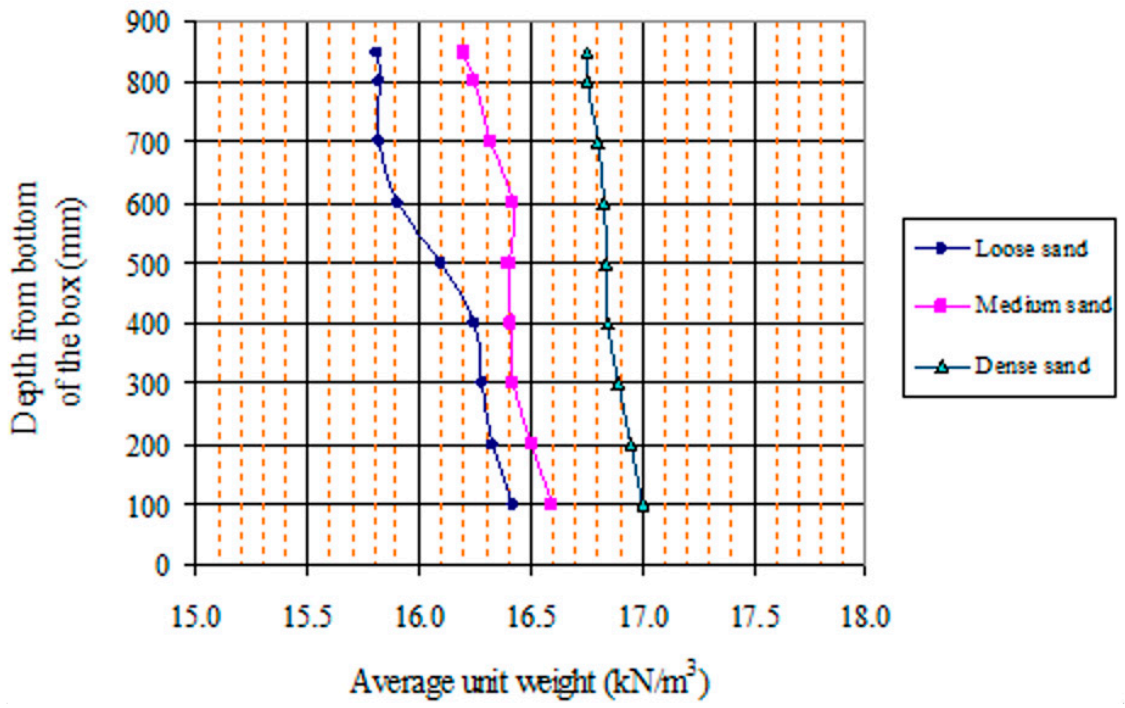

Figure 7. Density obtained at various depths of sand beds. 


\subsection{Nailed Soil Slope Modeling}

The laboratory models with a scale of 1:10 and a soil slope of 400 were prepared to determine the pullout resistance of the nails at different footing pressures. The slope height $(\mathrm{H})$ is taken as $700 \mathrm{~mm}$. The construction of the slope-nailed system and loading stages are shown in Figure 8. The footing pressure is applied on the slope nailed system through a footing plate of a width (B) of $150 \mathrm{~mm}$. The footing plate is placed at 1.5 times the width of the plate (i.e., $X=225 \mathrm{~mm}$ ) from the crest of the slope. The length of horizontal nails ( $\mathrm{Ln}$ ) is taken to be equal to slope height $(700 \mathrm{~mm})$ in the models. The vertical spacing $(\mathrm{Sv})$ and horizontal spacing $(\mathrm{Hv})$ of nails are provided as 0.4 times the slope height. Readings for force and displacement in the nail are measured during the construction of the slope and after each increment of footing pressure (q) from 5.0, 10.0, 20.0, to $30.0 \mathrm{kPa}$.

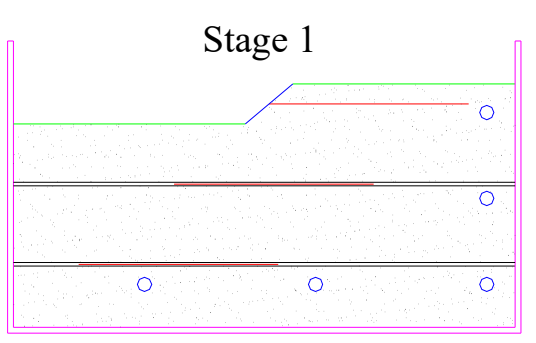

excvate the first layer $(140 \mathrm{~mm})$, put wall face, pull upper tube, hammer unmeasured nails and assign upper dail gauge

(a)

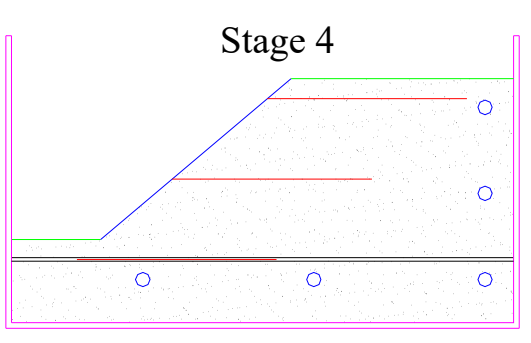

excvate the fourth layer $(140 \mathrm{~mm})$ and put the fourth wall face pannel.

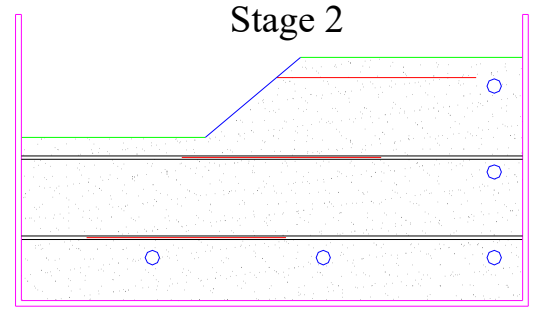

excvate the second layer $(140 \mathrm{~mm})$ and put the second wall face pannel.

(b)

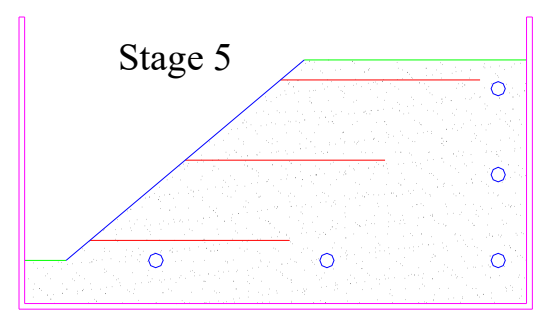

excvate the fifth layer $(140 \mathrm{~mm})$, put wall face, pull lower tube, hammer unmeasured nails and assign lower dail gauge

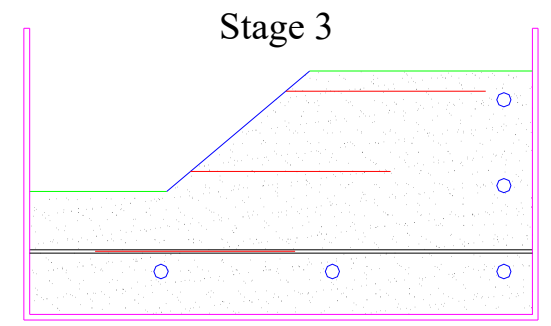

excvate the third layer $(140 \mathrm{~mm})$, put wall face, pull middel tube, hammer unmeasured nails and assign middel dail gauge

(c)

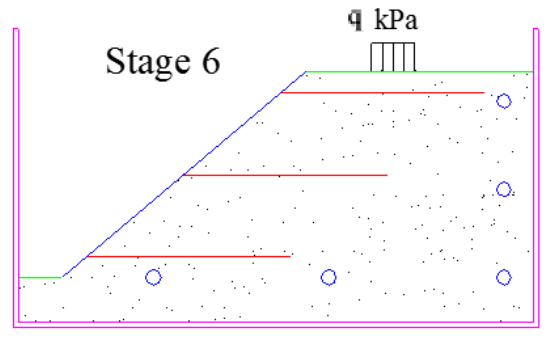

apply footing pressure of $5,10,20,30 \mathrm{kPa}$

(f)

Figure 8. Construction of the slope-nailed system and loading stages.

\subsection{Pullout Testing System}

A special system is designed to measure the pull-out resistance of nails as shown in Figure 9. The system consisted of a driven system and a load cell to measure the tensile force. The experimental set-up for the pullout test in a nailed soil slope is shown in Figure 10. The pull-out test was carried out according to the following steps:

- Step 1. Adjust the height of the pulling system according to the position and inclination of the nails;

- Step 2. Attach the nail to the pulling beam by means of wire and locking nut. The load cell is connected to the wire and the pulling beam;

- Step 3. Adjust the pulling speed by means of inverter and Potentiometer to 300 r.p.m, which corresponds to a horizontal speed of $0.282627 \mathrm{~mm} / \mathrm{min}$;

- Step 4. Switch on the inverter power and measure the pulling load every two seconds to give a displacement interval of $0.01 \mathrm{~mm}$ until the stroke equal to $10 \mathrm{~mm}$ or the reading of the load cell become constant with the increasing displacement. 


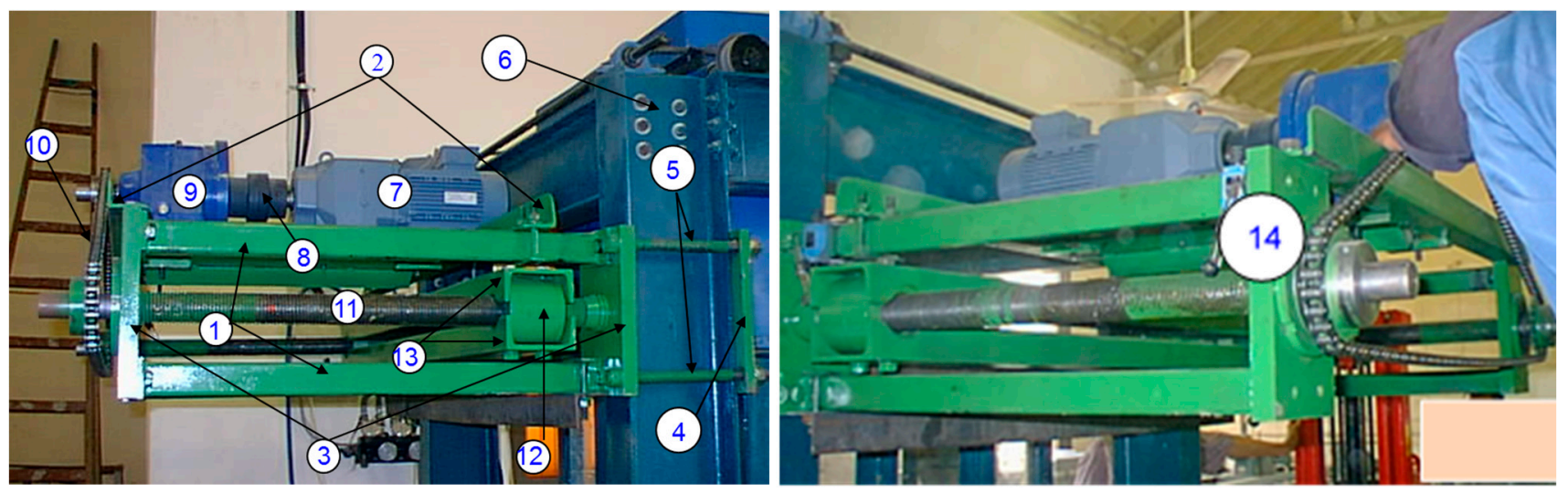

Figure 9. Nail pullout system. 1: 4 Beams of box section; 2: 4 connected angles; 3: 4 plates $280 \times 160 \times 25 \mathrm{~mm}$; 4 : 2 plates $280 \times 160 \times 20 \mathrm{~mm}$; 5: 8 screws $20 \mathrm{~mm}$ in diameter; 6: loading frame; 7: electrical gear motor; 8: coupling; 9: gear box; 10: chain; 11: two power screw rods; 12: two big nuts; 13: pulling beam; 14: two limit switch.

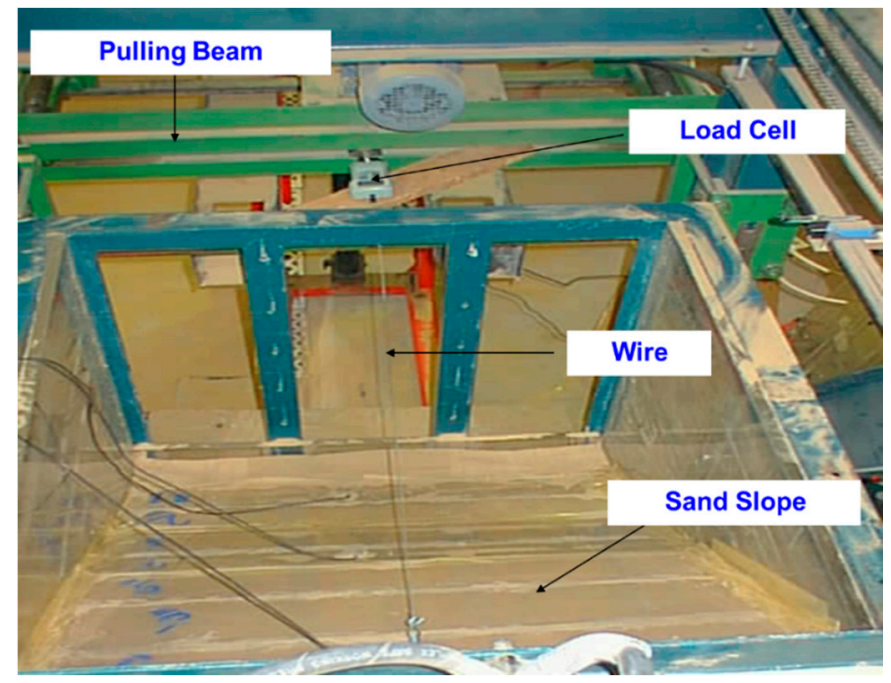

Figure 10. Experimental set-up for pullout test.

\subsection{Finite Element Modeling}

The finite element model of nail-reinforced soil slopes was developed to validate the laboratory model results. The nailed soil slope parameters used in the model are given in Table 4. The PLAXIS-2D code was used to develop a finite element modeling of nailed soil slopes considering a plane strain condition. The suitable elements available in PLAXIS were used to model the sand, steel, and Perspex glass material. The 15-node triangular elements available in the PLAXIS code were employed for soil modeling. The 15-node triangle element with 12 nodes on the sides and 3 nodes on the inside of the triangle is a proven element to give a robust solution for large deformation geotechnical problems. The five node plate elements were used for footing modeling. The two node elastic spring elements were used to model nail reinforcements. The interface elements were used to model the interaction between the component of the nailed soil slope. A nonlinear elastic (Hyperbolic) model was used to simulate the sand material. The soil parameters used in the material model are given in Table 5. The discretized nailed soil slope finite element model with boundary conditions is shown in Figure 11. The published literature by the authors [23] presents the validation results obtained by the soil slope finite element models. 
Table 4. Nailed soil slope parameters.

\begin{tabular}{|c|c|c|c|c|c|c|c|c|c|c|c|}
\hline Paramete & $\mathrm{A}(\mathrm{mm})$ & $\begin{array}{c}\text { B } \\
(\mathrm{mm})\end{array}$ & $\begin{array}{c}\mathrm{Y} \\
(\mathrm{mm})\end{array}$ & $\begin{array}{c}\mathrm{Z} \\
(\mathrm{mm})\end{array}$ & $\begin{array}{c}X \\
(\mathrm{~mm})\end{array}$ & $\begin{array}{c}\mathrm{Sh}=\mathrm{Sv} \\
(\mathrm{mm})\end{array}$ & $\begin{array}{c}\text { Slope } \\
\text { Angle }\left({ }^{\circ}\right)\end{array}$ & $\begin{array}{c}\text { Nail } \\
\text { Inclination }\left({ }^{\circ}\right)\end{array}$ & $\begin{array}{c}\mathrm{H}=\mathrm{Ln} \\
(\mathrm{mm})\end{array}$ & $\begin{array}{l}\text { RD } \\
(\%)\end{array}$ & $\underset{(\mathbf{k P a})}{q}$ \\
\hline Value & 405 & 150 & 834 & 146 & 225 & 280 & 40 & 0 & 700 & 48 & $\begin{array}{l}5,10 \\
20,30\end{array}$ \\
\hline
\end{tabular}

A-Soil width beyond the footing; B —-footing width; Y - soil width beyond the toe of slope; Z— soil base depth below the slope; X-distance of footing from crest; $\mathrm{Sv} —$ nail vertical spacing; $\mathrm{Sh} —$ nail horizontal spacing; H—excavation height; Ln—nail length; RD—relative density of the sand; $\mathrm{q}$-footing pressure.

Table 5. Material Model Parameters for granular material (Sand).

\begin{tabular}{|c|c|c|c|c|c|c|c|c|c|}
\hline \multirow{2}{*}{$\begin{array}{c}\text { Bulk } \\
\text { Density } \\
\left(\mathbf{k N} / \mathrm{m}^{3}\right)\end{array}$} & \multicolumn{4}{|c|}{$\begin{array}{l}\text { Material Model } \\
(\text { Mohr-Coulomb) }\end{array}$} & \multirow{2}{*}{$\begin{array}{c}\text { Plastic Straining } \\
\text { Due to Deviator } \\
\text { Loading }\left(E_{50}\right)^{\text {ref }} \\
(\mathbf{k P a})\end{array}$} & \multirow{2}{*}{$\begin{array}{c}\text { Plastic Straining } \\
\text { Due to Primary } \\
\text { Comp. }\left(\mathrm{E}_{\mathrm{oed}}\right)^{\text {ref }} \\
(\mathrm{kPa})\end{array}$} & \multicolumn{2}{|c|}{$\begin{array}{c}\text { Elastic } \\
\text { Unloading/Reloading }\end{array}$} & \multirow{2}{*}{$\begin{array}{l}\text { Stress De- } \\
\text { pendent } \\
\text { Stiffness } \\
(\mathrm{m})\end{array}$} \\
\hline & $\varphi$ & $\begin{array}{c}\mathrm{C} \\
(\mathbf{k P a})\end{array}$ & $\psi$ & $v$ & & & $\begin{array}{c}\left(E_{u r}\right)^{\text {ref }} \\
(\mathbf{k P a})\end{array}$ & $v_{\mathrm{ur}}$ & \\
\hline 16.41 & 34 & 0.2 & 4 & 0.31 & 1959 & 1959 & 5877 & 0.2 & 0.5 \\
\hline
\end{tabular}

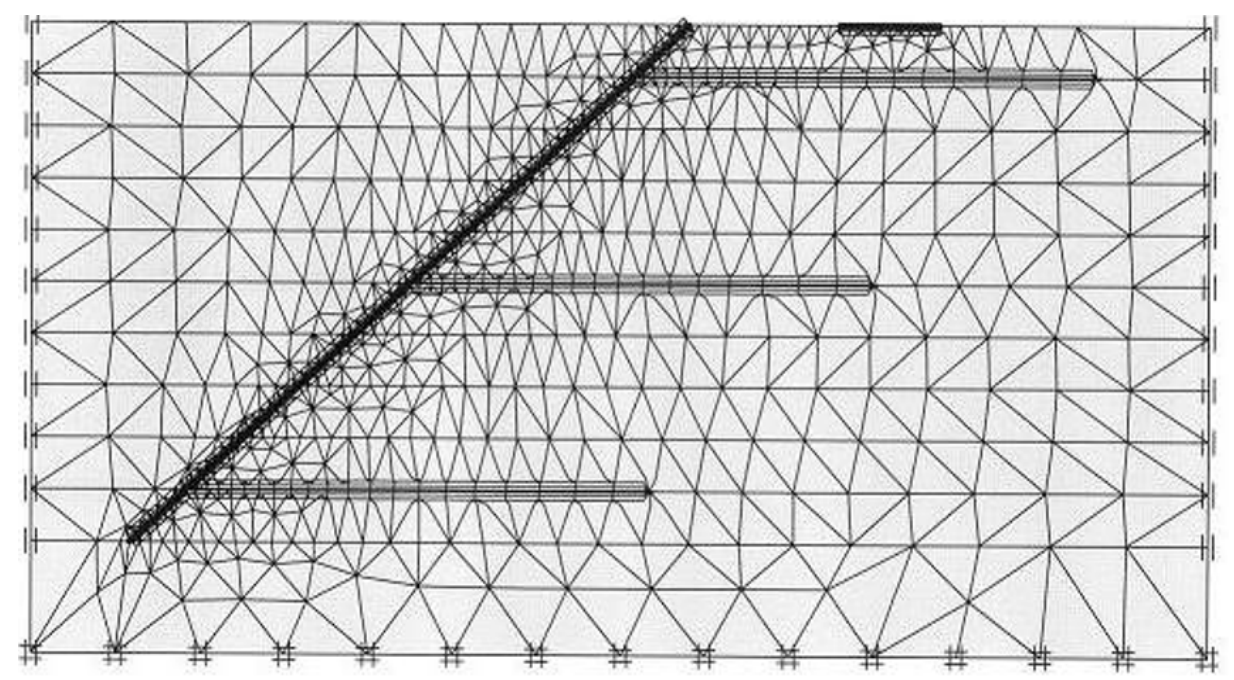

Figure 11. Discretized finite element model of nailed soil slope.

\section{Results and Discussion}

The laboratory and finite element models, constructed and discussed above, are tested to investigate the performance of the nailed soil slope under overburden pressure. Figure 12 shows the mobilization of the pullout force in nails placed at different levels within the soil slope (upper, middle, and lower nail) in the case of no footing without any overburden pressure and at an overburden pressure of $5 \mathrm{kN}$ and $10 \mathrm{kN}$. It can be seen from the figures that the pullout force in the nails increases as the displacement increases. However, the increase in the pullout force is not same in the nails of different levels and the maximum pullout force is also different at low values of overburden pressures. The pullout force reaches its maximum value rapidly in lower nails but in upper and middle nails it reaches its maximum value slowly, having no or a lower overburden pressure. This may be due to the change of over burden pressures which contribute to pullout resistance. The pullout force slightly decreases after reaching the peak and then become constant in lower nails, while it becomes constant immediately in the case of middle and upper nails after reaching the peak value. It can be observed from the figure that the rate of increase of the pullout force becomes almost the same in the upper, middle, and lower nails, with further increase of overburden pressure. 


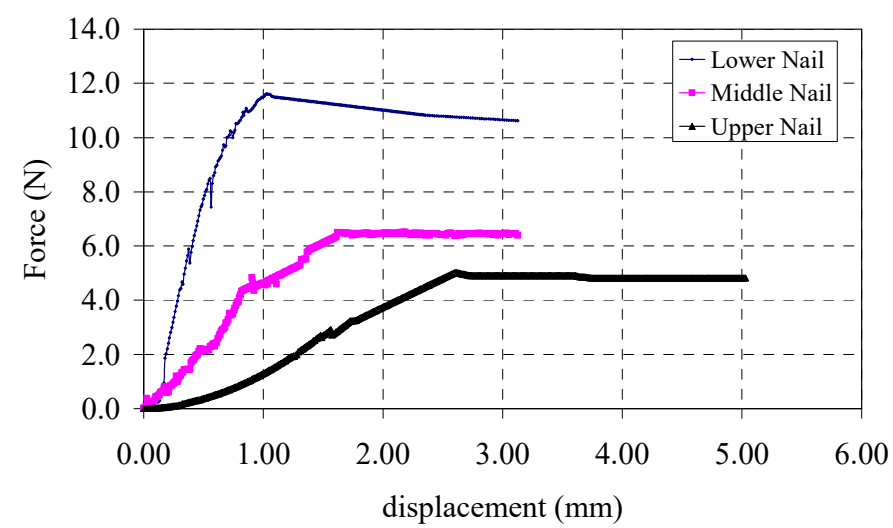

(a)

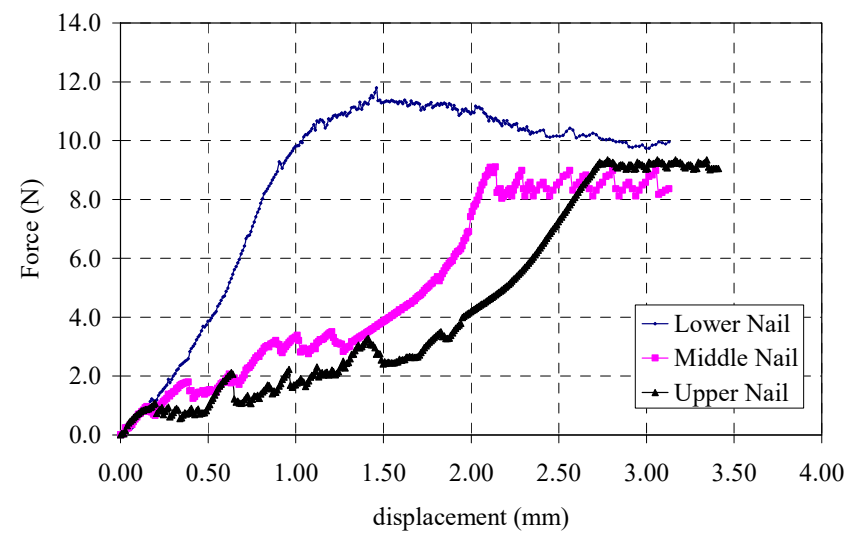

(b)

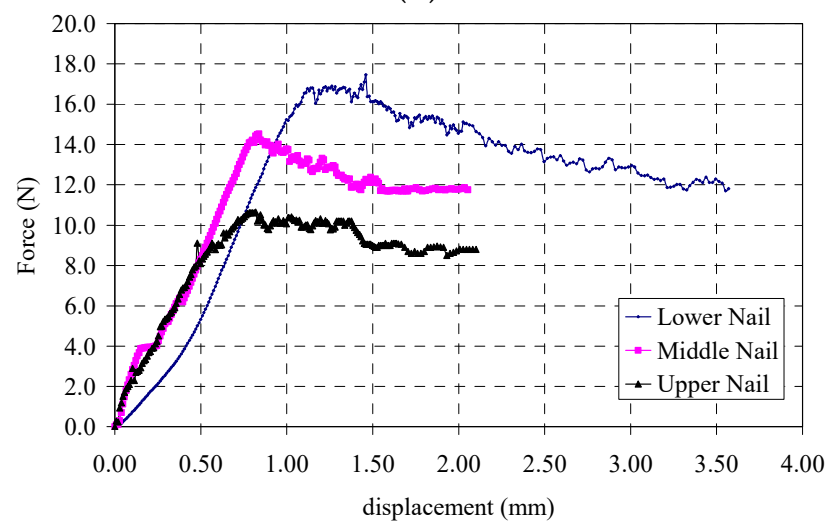

(c)

Figure 12. Pullout force of nails with displacement; (a) $q=0 \mathrm{kN} ;(\mathbf{b}) \mathrm{q}=5 \mathrm{kN} ;(\mathbf{c}) \mathrm{q}=10 \mathrm{kN}$.

The relationship between the displacement of the nail and the pullout force at three different levels of nails (upper, middle, and lower) and with footing pressure of $20.0 \mathrm{kPa}$ and $30.0 \mathrm{kPa}$ are presented in Figure 13. From the figures, it can be seen that the maximum value of the pullout force is reached gradually in the upper nails and rapidly in the other two nails. In the lower and middle nails, the rate of increase of pullout force is very steep and becomes constant after reaching the peak value. There is a large difference in the mobilized peak value of the pullout force of lower nails, and the pullout forces of upper and middle nails. This difference is more than $100 \%$ from the pullout force of the upper and middle nails. 


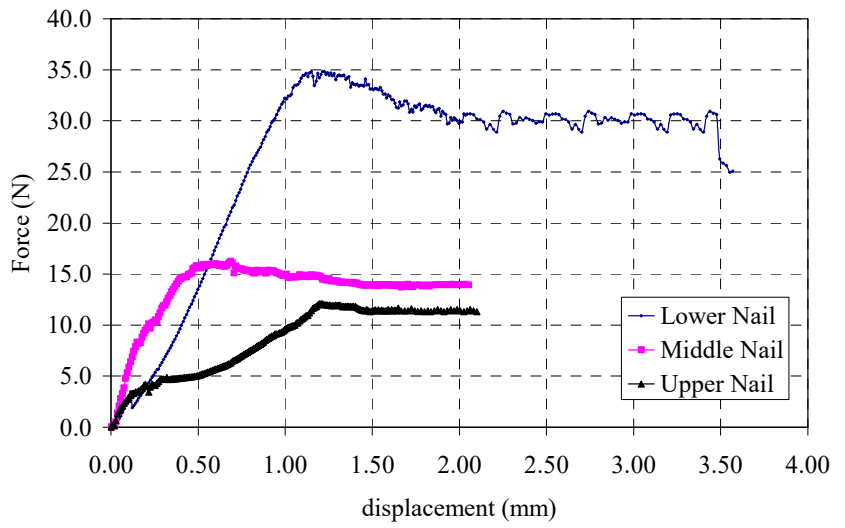

(a)

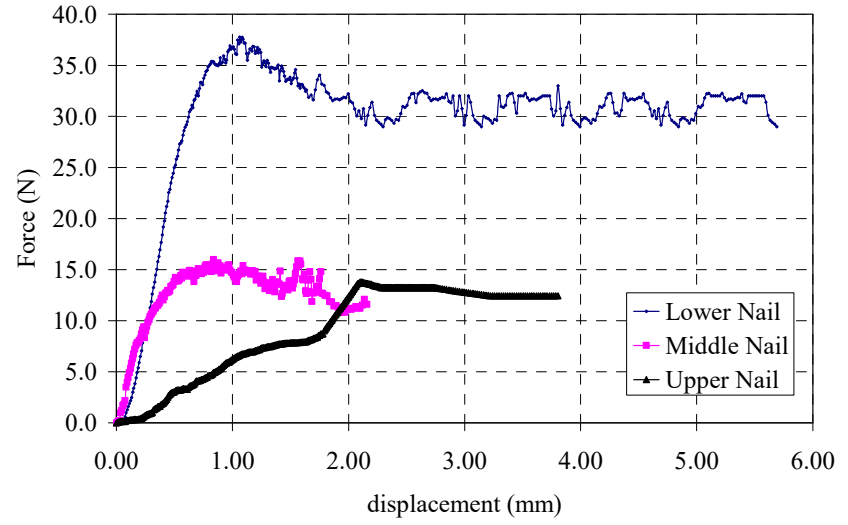

(b)

Figure 13. Pullout force of nails with displacement; (a) $q=20 \mathrm{kN} ;(\mathbf{b}) \mathrm{q}=30 \mathrm{kN}$.

Figure 14 shows the influence of the nail level at different footing pressures on the maximum pullout force of the nail. From this figure, it could be seen that the lower nail exerts more pull-out force than the middle nail and the least pull-out force occurs at the upper nail. This may be attributed to the fact that the lower nail has more overburden pressure than the middle and the upper nail. Moreover, the figure indicated that the influence of footing pressure on the pullout force is steep, increasing in the lower nail but slowly increasing or becoming constant in case of the middle and upper nail. The reason for this is that the lower nail has little movement, and these movements are enough to mobilize the maximum friction force and hence the pullout resistance and does not lose its value rapidly. Nevertheless, in the other two cases, the maximum values are reached after some time and gradually lose their values in a short time. However, the pullout behavior of nail reinforcement is affected by a number of factors and the present study results are compared with the existing literature results. Similar trends between the results were observed by Hong et al. [6] for the pullout behavior of nail reinforcement in a nailed soil slope.

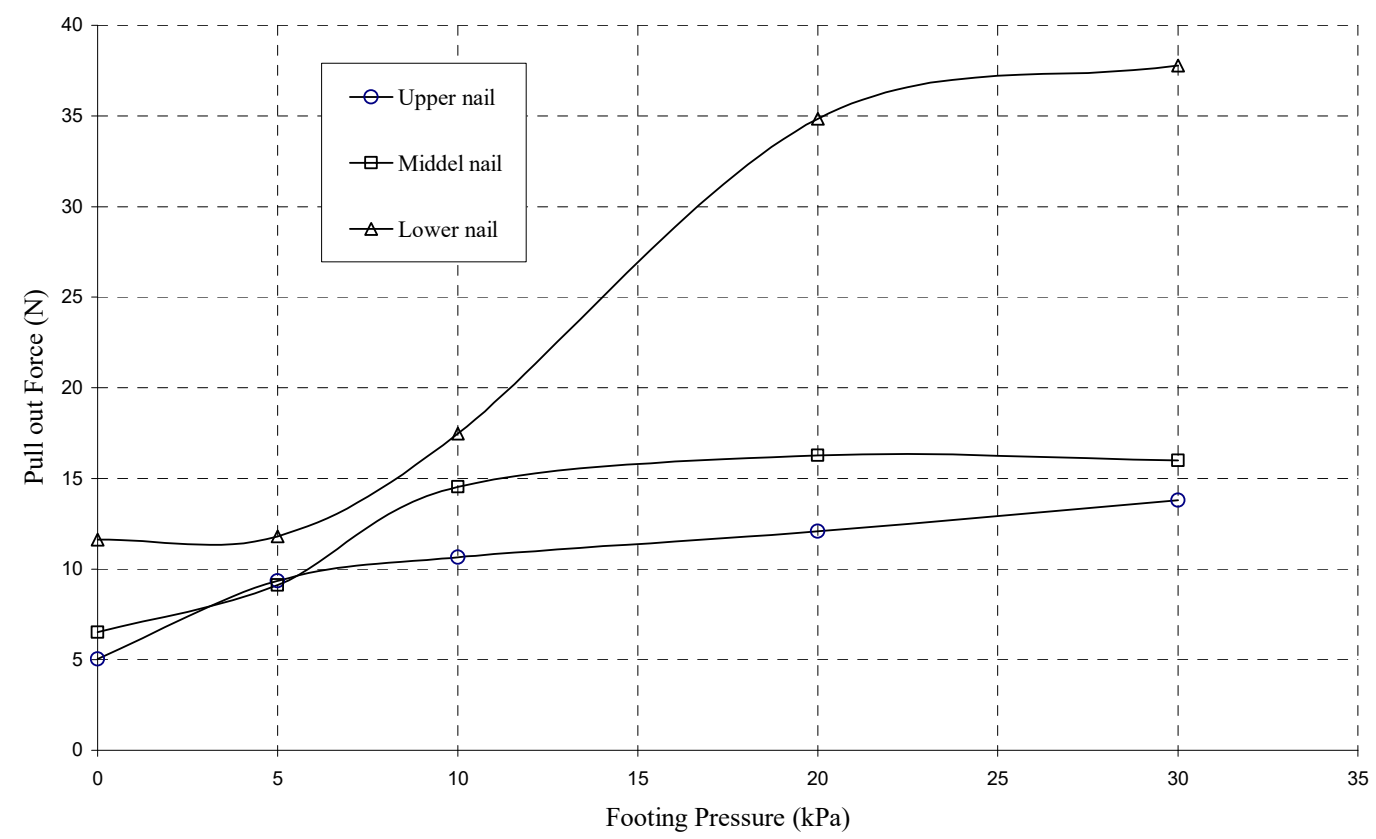

Figure 14. Maximum pullout force in nails at different footing pressures.

Finite element models were analyzed for the deformed shape of a nailed soil slope during the construction stage and loading stage, and for footing settlement at various footing 
pressures. The vertical and shear stress results are also obtained during the construction stage and loading stages. The results obtained from both laboratory and finite element models were compared at footing pressures of 0, 5, 10, 20 and $30 \mathrm{kPa}$. Figure 15 shows the deformed shape of the system during the construction stage and the loading stage.

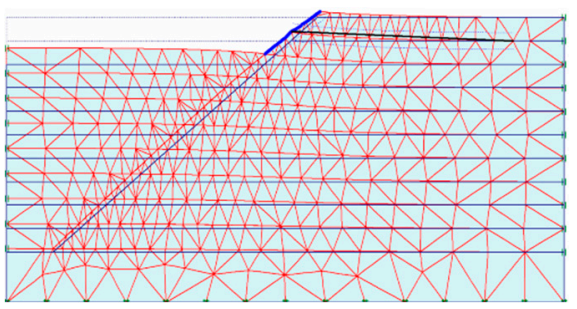

(a)

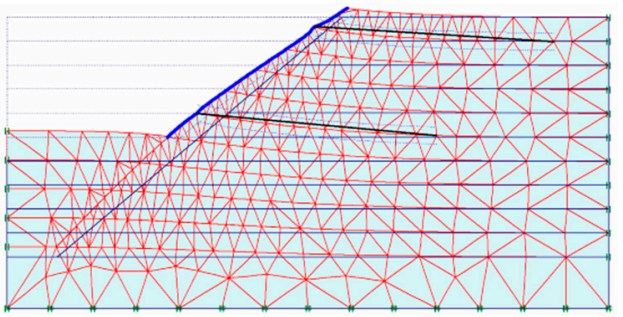

(b)

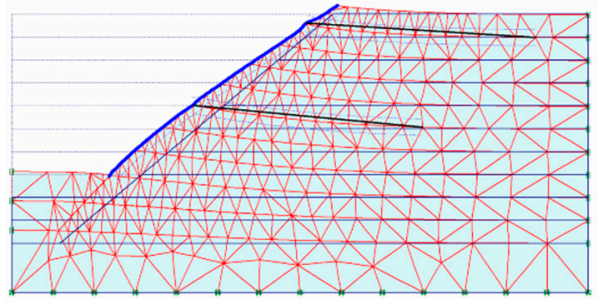

(c)

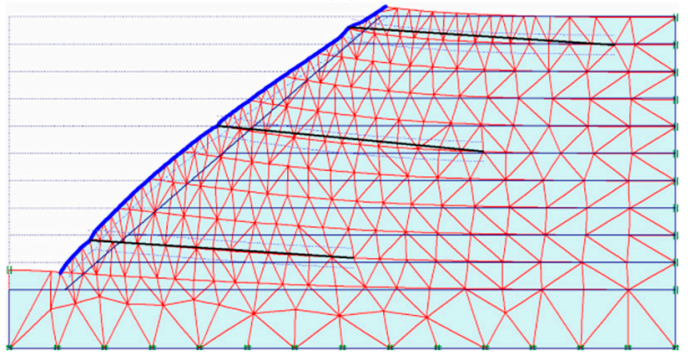

(d)

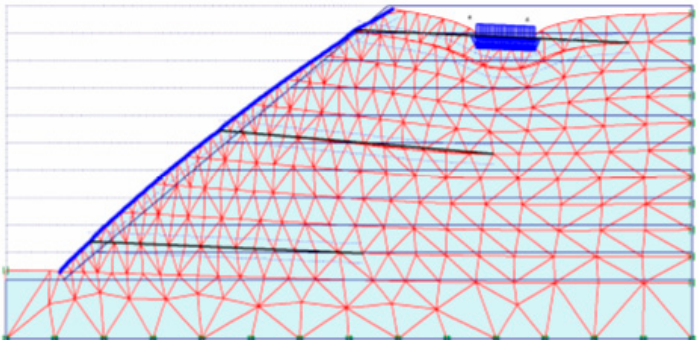

(e)

Figure 15. Deformed shape of the nailed soil system during the construction and loading stage; (a) deformed shape (stage 1); (b) deformed shape (stage 3); (c) deformed shape (stage 4); (d) deformed shape (stage 5); (e) deformed shape (stage 6, $q=30 \mathrm{kPa}$ ).

Table 6 represents a comparison of the footing settlement obtained, in terms of the fraction of the slope height $(\mathrm{S} / \mathrm{H})$, i.e., vertical settlement/slope height, in the laboratory and computational models. It is clear from the table that the maximum footing settlement 
occurs at a surcharge load exerting a foundation pressure of $30.0 \mathrm{kN} / \mathrm{m}^{2}$ in both the models. It can be inferred from the table that the laboratory model underestimates the footing settlements. The percentage of difference in settlement between the laboratory and numerical model ranges from $13.37 \%$ to $40.59 \%$.

Table 6. Comparison of footing settlement obtained in laboratory and computational models.

\begin{tabular}{cccccc}
\hline Footing pressure (kPa) & 0 & 5 & 10 & 20 & 30 \\
Footing settlement (Lab., \%) & 0 & 0.29 & 0.46 & 0.8 & 1.45 \\
Footing settlement (Comp., \%) & 0 & 0.265 & 0.5 & 1.13 & 1.95 \\
\hline
\end{tabular}

Figures 16-18 depict the vertical, horizontal and shear stresses during the construction stage and loading stages. It infers from the figures that vertical stresses increased with the depth and decreased under the slope with the excavation process and then in loading stages vertical stresses increased. The increase in vertical stress is reduced as we go far from the footing. The horizontal stresses increase gradually with the depth and increases as we go far from the slope face. These stresses increase with the excavation process then in the loading stages. The shear stresses increase near the top surface of the sand bed and face the slope as well as near and under the footing, while within the soil nailing mass the values are almost the same. Zero shear stresses, which are typically developed at the reinforced mass, indicates the changes in direction of shear stresses and should occur at these locations. In loading stages, the shear stresses are increased with the increase in the overburden pressure.

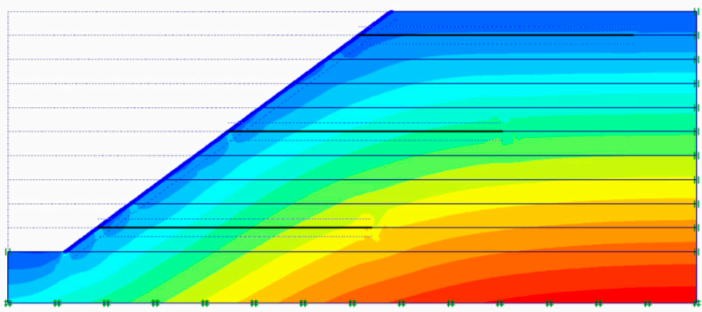

(a)

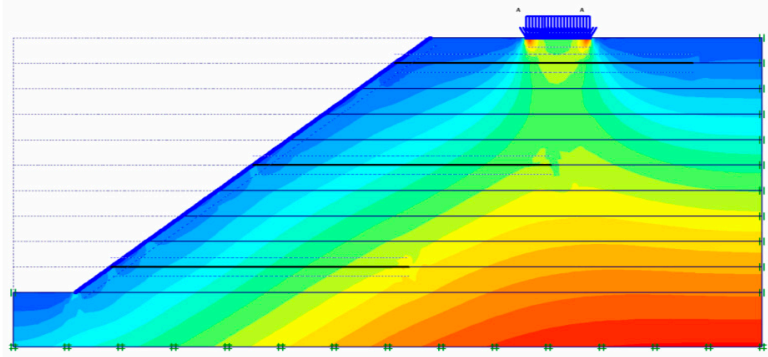

(b)

Figure 16. Vertical stress during construction and loading stage; (a) construction stage; (b) loading stage.

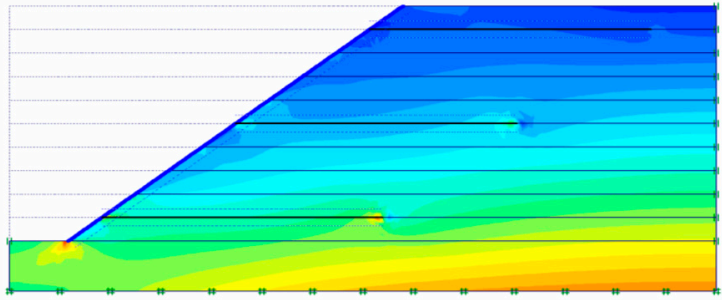

(a)
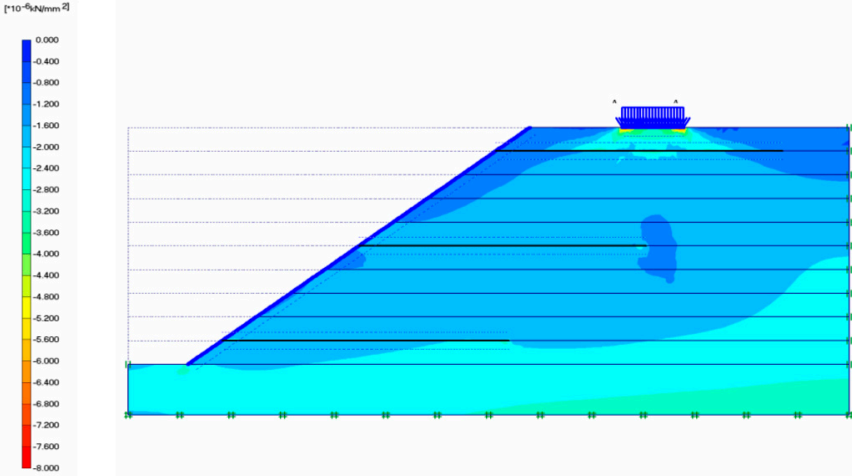

(b)

Figure 17. Horizontal stress during the construction and loading stage; (a) construction stage; (b) loading stage. 


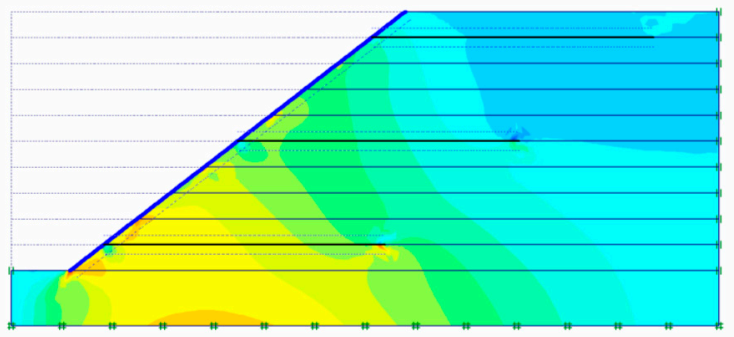

(a)

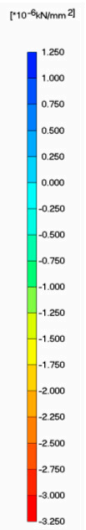

(b)

Figure 18. Shear stress during the construction and loading stage; (a) construction stage; (b) loading stage.

\section{Conclusions}

In this study, nail pullout tests were conducted to assess the pullout behavior of soil nail reinforcement at different levels in granular materials. The laboratory models of nailed soil systems of granular with a scale of 1:10 were prepared. The construction sequence used in a full scale slope was precisely followed in the laboratory model. The construction of the nailed soil slope system models, loading stages and pullout testing procedures were clearly defined. The models consisted of a Perspex wall box filled with sand and steel bars as a reinforcement. The models of sand beds were formed using an automatic sand raining system. The devices and instruments were installed to record the nail pullout resistance and displacement. The tests were carried out at variable footing pressure to get the pullout force of the nails, with a strain controller taking horizontal speed at $0.3 \mathrm{~mm} / \mathrm{min}$. The finite element models of nailed soil slope were also analyzed to validate the laboratory model results.

The following conclusions may be drawn from the present study.

- The pullout force was increased as the displacement of the nail increased until it reached the maximum pullout force and then decreased or became constant;

- The lower nail exerted a greater pullout force than the middle nail and the least pullout force occurred at the upper nail. This may be attributed to the fact that the lower nail had a greater overburden pressure than the middle and the upper nails;

- There was a steep increase in the pullout force in the lower nail with an increase in the footing pressure, whereas in case of the middle nail, there was a slight increase with the increase in footing pressure;

- In the upper nail, the rate of increase of pullout forces changed from a high increase to a constant, whereas in case of the middle nail, the rate of increase of pullout forces increased slowly and became constant;

- The numerical model results point out that the laboratory models underestimate the pullout behavior of nail reinforcement in nailed soil slopes.

Author Contributions: Conceptualization, M.H.M. and M.A.; methodology, M.H.M. and M.A.; resources, J.M.; writing — original draft preparation, M.H.M. and M.A., writing—review and editing, J.M., project administration; funding acquisition, M.A. All authors have read and agreed to the published version of the manuscript.

Funding: Funding for this research was given under award numbers R.G.P2/73/41 by the Deanship of Scientific Research; King Khalid University, Ministry of Education, Saudi Arabia.

Institutional Review Board Statement: Not applicable.

Informed Consent Statement: Not applicable.

Data Availability Statement: Not applicable. 
Acknowledgments: The authors extend their appreciation to the Deanship of Scientific Research at King Khalid University for funding this work through General Research Project under grant number (R.G.P2/73/41), The authors acknowledge to the Dean, Faculty of Engineering for valuable support and help.

Conflicts of Interest: The authors declare no conflict of interest.

\section{References}

1. Franzen, G.; Jendeby, L. Prediction of Pull-out Capacity of Soil Nails. In Proceedings of the Fifteenth International Conference on Soil Mechanics and Geotechnical Engineering ICSMGE, Istanbul, Turkey, 27-31 August 2001; Volume 2.

2. Oliaei, M.; Norouzi, B.; Binesh, S.M. Evaluation of soil-nail pullout resistance using mesh-free method. Comput. Geotech. 2019, 116, 103179. [CrossRef]

3. Panigrahi, R.K.; Dhiman, G. Design and Analysis of Soil Nailing Technique for Remediation of Landslides. Highw. Res. J. 2019, 10, 24-32.

4. Hu, H.; Lin, P. Analysis of resistance factors for LRFD of soil nail pullout limit state using default FHWA load and resistance models. Mar. Georesources Geotechnol. 2020, 38, 332-348. [CrossRef]

5. Hong, C.-Y.; Yin, J.-H.; Zhou, W.-H.; Pei, H.-F. Analytical Study on Progressive Pullout Behavior of a Soil Nail. J. Geotech. Geoenviron. Eng. 2012, 138, 500-507. [CrossRef]

6. Luo, S.Q.; Tan, S.A.; Cheang, W.; Yong, K.Y. Elastoplastic analysis of pull-out resistance of soil nails in dilatant soils. Proc. Inst. Civ. Eng. Ground Improv. 2002, 6, 153-161. [CrossRef]

7. Su, L.-J.; Yin, J.-H.; Zhou, W.-H. Influence of Overburden Pressure and Soil Dilation on Soil Nail Pull-Out Resistance. Comput. Geotech. 2010, 37, 555-564. [CrossRef]

8. Hong, C.-Y.; Yin, J.-H.; Pei, H.-F.; Zhou, W.-H. Experimental Study on the Pullout Resistance of Pressure-Grouted Soil Nails in the Field. Can. Geotech. J. 2013, 50, 693-704. [CrossRef]

9. Cheuk, C.Y.; Ng, C.W.W.; Sun, H.W. Numerical Experiments of Soil Nails in Loose Fill Slopes Subjected to Rainfall Infiltration Effects. Comput. Geotech. 2005, 32, 290-303. [CrossRef]

10. Pradhan, B.; Tham, L.G.; Yue, Z.Q.; Junaideen, S.M.; Lee, C.F. Soil-Nail Pullout Interaction in Loose Fill Materials. Int. J. Geomech. 2006, 6, 238-247. [CrossRef]

11. Chen, C.; Zhang, G.; Zornberg, J.G.; Zheng, X. Element Nail Pullout Tests for Prediction of Soil Nail Pullout Resistance in Expansive Clays. Geotech. Test. J. 2019, 42, 1274-1297. [CrossRef]

12. Ye, X.; Wang, S.; Wang, Q.; Sloan, S.W.; Sheng, D. Numerical and experimental studies of the mechanical behaviour for compaction grouted soil nails in sandy soil. Comput. Geotech. 2017, 90, 202-214. [CrossRef]

13. Lin, P.; Liu, J. Evaluation and calibration of ultimate bond strength models for soil nails using maximum likelihood method. Acta Geotech. 2020, 15, 1993-2015. [CrossRef]

14. Li, L.-H.; Chen, Y.-J.; Ferreira, P.M.V.; Liu, Y.; Xiao, H.-L. Experimental Investigations on the Pull-Out Behavior of Tire Strips Reinforced Sands. Materials 2017, 10, 707.

15. Moayed, R.Z.; Namae, A. Evaluation of the Pullout Resistance of Soil Nails in Tehran Alluvium by Considering the Overburden Pressure Effect. Geotech. Geol. Eng. 2020, 38, 743-754. [CrossRef]

16. Luo, S.Q.; Tan, S.A.; Yong, K.Y. Pull-Out Resistance Mechanism of a Soil Nail Reinforcement in Dilative Soils. Soils Found. 2000, 40, 47-56. [CrossRef]

17. Zhou, W.-H.; Yin, J.-H.; Hong, C.-Y. Finite Element Modelling of Pullout Testing on a Soil Nail in a Pullout Box under Different Overburden and Grouting Pressures. Can. Geotech. J. 2011, 48, 557-567. [CrossRef]

18. Tokhi, H.; Ren, G.; Li, J. Laboratory study of a new screw nail and its interaction in sand. Comput. Geotech. 2016, 78, 144-154. [CrossRef]

19. Ruggeri, P.; Fruzzetti, V.M.E.; Scarpelli, G. The Behavior of a Thread-Bar Grouted Anchor in Soils from Local Strain Monitoring. Appl. Sci. 2020, 10, 7194. [CrossRef]

20. Sharma, P.; Rawat, S.; Gupta, A.K. Laboratory investigation of pullout behavior of hollow and solid shaft helical nail in frictional soil. Acta Geotech. 2021, 16, 1205-1230. [CrossRef]

21. Ehrlich, M.; da Rosa, C.A.B.; Mirmoradi, S.H. Effect of construction and design factors on the behaviour of nailed-soil structures. Proc. Inst. Civ. Eng. Geotech. Eng. 2021, 1-13. [CrossRef]

22. Chen, C.; Zhu, S.; Zhang, G.; Mao, F.; Cai, H. Time-dependent load transfer behavior of grouted anchors in laterite. Comput. Geotech. 2021, 132, 103969. [CrossRef]

23. Mohamed, M.H.; Ahmed, M.; Mallick, J.; Hoa, P.V. An Experimental Study of a Nailed Soil Slope: Effects of Surcharge Loading and Nails Characteristics. Appl. Sci. 2021, 11, 4842. [CrossRef] 